\title{
COMMUNITY NURSES' PERCEPTIONS OF AND EXPOSURE TO CHILDREN WITH SEVERE DISABILITIES AND THEIR PRIMARY CAREGIVERS
}

\section{Juan Bornman}

$\mathrm{PhD}$

Senior lecturer, Centre for Augmentative and Alternative Communication, University of Pretoria

Corresponding Author: bornman@postino.up.ac.za

\section{Erna Alant \\ D.Phil \\ Professor, Centre for Augmentative and Alternative Communication, University of Pretoria}

Key words: Augmentative and alternative communication; community nurses; primary health care; primary care givers; severe disability.

$\begin{array}{ll}\text { List of abbreviations: } \\ \text { AAC } & \text { Augmentative and alternative communication } \\ \text { AIDS } & \text { Acquired immune deficiency syndrome } \\ \text { CP } & \text { Cerebral Palsy } \\ \text { CSD } & \text { Children with severe disabilities } \\ \text { HIV } & \text { Human immune deficiency virus } \\ \text { II } & \text { Intellectual impairment } \\ \text { LNFS } & \text { Little or no functional speech } \\ \text { PHC } & \text { Primary health care } \\ \text { SLT } & \text { Speech language therapist } \\ \text { TB } & \text { Tuberculosis } \\ \text { WHO } & \text { World Health Organisation }\end{array}$

\begin{abstract}
In primary health care clinics nurses are faced with individuals of different ages with different problems, ranging from minor ailments to severe disabilities. Particularly vulnerable are those with severe disabilities, with specific reference to those with communication and intellectual impairments because of their inability to articulate their needs, feelings and rights. Community nurses are often the first contact that primary caregivers (parents) of children with severe disabilities (CSDs) have with health professionals and they often remain the only professionals who support and assist these caregivers. It is therefore clear that these nurses need to be equipped with the necessary knowledge and skills to assist caregivers in dealing with their CSDs.

This is a descriptive study aimed at determining community nurses' perceptions regarding disability and their exposure to CSDs. Quantitative (questionnaire) and qualitative (focus groups) methods were used to obtain data. Results indicated that nurses regarded their knowledge and skills in dealing with CSDs and their caregivers as inadequate, despite the fact that they were exposed to them and were expected to provide services to them. A need for knowledge and skill training in this regard was identified.
\end{abstract}

\section{OPSOMMING}

In primêre gesondheidsorgklinieke kom verpleegkundiges in aanraking met individue van verskillende ouderdomme met ' $n$ verskeidenheid probleme, wat strek vanaf geringe kwale tot erge gestremdhede. ' $n$ Besonder weerlose groep is persone met erge gestremdhede, met spesifieke verwysing na dié met kommunikasie- en intellektuele 
gebreke as gevolg van hul onvermoë om hul behoeftes, gevoelens en regte te verwoord. Gemeenskapsverpleegkundiges is dikwels die eerste kontak wat primêre versorgers (ouers) van kinders met erge gestremdhede met professionele persone in die gesondheidssektor het, en hulle bly gewoonlik die enigste professionele persone wat ondersteuning en leiding aan hierdie versorgers verskaf. Gevolglik is dit duidelik dat hierdie verpleegkundiges met die nodige kennis en vaardighede toegerus moet word om versorgers te ondersteun in die hantering van hul kinders met gestremdhede.

Hierdie is ' $n$ beskrywende studie wat daarop gerig is om gemeenskaps-verpleegkundiges se persepsies rakende gestremdheid te bepaal, asook hul blootstelling aan kinders met erge gestremdhede. Kwantitatiewe (vraelys) sowel as kwalitatiewe (fokusgroep) metodes is gebruik om die data te verkry. Resultate het daarop gedui dat verpleegkundiges hul kennis en vaardighede in die hantering van kinders met erge gestremdhede en hul primêre versorgers as ontoereikend ervaar, desnieteenstaande die feit dat hulle aan hierdie populasie blootgestel is en dat daar van hulle verwag word om dienste aan hulle te lewer. Die behoefte aan kennis- en vaardigheidsopleiding in hierdie verband is geïdentifiseer.

\section{INTRODUCTION}

Since the birth of South Africa's democracy in 1994, a new health policy, namely primary health care $(\mathrm{PHC})$ was accepted in order to address equality in health services given the manpower and resource constraints of the developing world (Department of Health, 1999:4). The Alma Ata declaration identified PHC as "... essential health care made universally accessible to individuals and families in the community by means acceptable to them, through their full participation and at a cost that the community and country can afford" (WHO/ UNICEF in Rifkin, 1986:240). PHC is thus not only seen as the first level of care, but rather as a reorientation of the health care system from its present concentration on late stage, high technology hospital services to community and preventive services (Willis, Biggins \& Donovan, 1999:210). In order to meet the needs of as large a number of people as possible in a culturally appropriate, cost effective way, all possible resources must therefore be utilised (House, McAlister \& Naidoo, 1990:18; Stanhope, 1995:50). Consequently professionals began to realise that primary caregiver involvement is central to service delivery, that a high degree of collaboration and joint decision-making between primary caregivers and professionals should be established so that a joint vision and joint decision-making can be achieved, and that the cross-training of professionals and paraprofessionals in providing services to everyone should be highlighted (Chapman \& Ware, 1999:105; O'Toole, 1988:324). These three aspects form the basis of a transdisciplinary approach to service delivery - an approach that not only reduces the duplication of services, but one that also addresses the fragmentation that currently exists amongst differ- ent service providers. The transdisciplinary approach is therefore closely linked to PHC as it becomes meaningful within a more comprehensive model of service delivery.

Nurses are the frontline practitioners in the provision of PHC services. Community nurses do not merely perform nursing activities in the community setting. Their task should rather be seen as the provision of ongoing, comprehensive and general practice that is not limited to a specific age or diagnostic group aimed at the promotion of health and the prevention of illness (Clark, 1996:18; Lerner \& Ross, 1991:47). Community nursing therefore "requires planning and sharing with others in the community to promote health for the community, family and individual. Through the collaborative process, the special abilities of others are used to communicate, plan, solve problems and evaluate services" (Standards for Community Nursing in Wilkey \& Gardner, 1999:307). The role of the nurse has thus shifted away from the role of servant to the medical profession towards the role of helper and partner of people and communities.

One particularly vulnerable group of individuals within communities is children with severe disabilities (CSDs). It is evident that there is a high incidence of disability in South Africa. It is estimated that $5-12 \%$ of South Africans are moderately to severely disabled (NPA, 1999:9). Of South Africa's total population of 40 million, $73 \%$ are women and children (Government Gazette no 17910,1997:11) placing them at a higher risk of disability (Ramey \& Ramey, 1992:337). More than 
$80 \%$ of black children with a disability live in extreme poverty and have poor access to appropriate health facilities or early childhood developmental opportunities (NPA, 1999:9). In the sphere of individuals with severe disabilities a particularly neglected group is that of individuals with communication and intellectual impairments due to their inability to articulate their needs, feelings and rights (Thorburn \& Marfo, 1990:180). A study conducted in schools for children with cognitive impairment in and around Pretoria indicated that $39 \%$ of these children were using less than 15 intelligible words (Bornman \& Alant, 1997:17). This percentage is significantly higher than that in comparable international studies such as the $2,4 \%$ reported in North Dakota (Burd, Hammes, Bornhoeft \& Fisher, 1988:376) and $6 \%$ in rural areas in Washington State (Matas, Mathy-Laikko, Beukelman \& Legresley, 1985:26). There are different reasons for this, including the fact that persons with severe disabilities in South Africa are not exposed to Augmentative and Alternative Communication (AAC) strategies, as it is still a relatively new field of expertise in this country. Internationally it is also reported that programmes to specifically address the communication needs by equipping these children with the necessary skills to interact, are limited (Werner, 1987:3-10).

Apart from the high incidence of disability in developing countries, these individuals also share commonalties in terms of the services offered. It is well documented in the literature that people with severe disabilities receive less education and vocational training, and are often unemployed, resulting in poverty (Lundgren-Lindquist \& Nordholm, 1993:83). The aura of charity still pervades many of the services offered and rarely are the persons with disabilities given the opportunity to help themselves (McConkey, 1996:28). Due to long held low expectations of people with severe disabilities, they are often excluded from leadership positions or from any planning and decision-making in their communities, resulting in a lack of representation of their needs.

In addition, very few professionals in South Africa are trained in AAC implementation, and are thus unable to provide AAC intervention to people in need. This is due to the fact that communication intervention for children with severe disabilities (CSDs) has not been a priority, and that international sanctions limited South Africa's participation in the international AAC field until the early nineties. In addition, the majority of services provided by professionals are located in a few large cities, making it inaccessible to the rural population, leading to services being provided to less than three percent of disabled people in need (Thorburn \& Marfo, 1990:22). Professionals also tend to work in isolation with minimal integration between services, which led many people to believe that service provision to disabled people was too complicated to be administered by persons other than professionals. It was thought that any other form of rehabilitation would be ineffective (Thorburn \& Marfo, 1990:24).

When placing disability within the $\mathrm{PHC}$ paradigm, it is clear that the first contact that many CSDs and their primary caregivers have with professionals, is contact with community nurses. This is due to a number of factors, including the relative ease of access to primary health care clinics for South Africans, even those living in rural and remote areas; the fact that primary caregivers attend well-baby clinics and also visit these clinics for inoculations; and the fact that community nurses are often the only health professionals in the area. Furthermore, these nurses often remain the only professionals who provide support and assistance to caregivers of pre-school children.

Little information is, however, available as to community nurse's perceptions regarding CSDs; their exposure to CSDs and how they perceive the needs of CSDs and their primary caregivers. This information is central when planning a training programme for nurses to equip them with the necessary skills and expertise to assist primary caregivers in dealing with their CSDs. The current research project therefore discusses the issue of nurse's perceptions in dealing with CSDs and their primary caregivers. In order to achieve this a descriptive needs analysis was conducted.

\section{AIMS OF THE STUDY}

The main aim of this study was to conduct a needs analysis in order to:

- ascertain the perceptions of community nurses regarding service delivery to CSDs;

- determine the exposure of community nurses to 
CSDs;

- establish how community nurses perceive the needs of CSDs and their primary caregivers.

\section{RESEARCH DESIGN AND METHO- DOLOGY}

A descriptive design was used employing both quantitative and qualitative measures, as it would be appropriate in meeting the aims of the study (Leedy, 2001:191). Quantitative data was obtained by using a short two-page questionnaire that was developed specifically for this purpose. Qualitative data, on the other hand, was obtained by conducting two focus groups with community nurses as they yield information from multiple sources, contain rich contextual data and are also excellent tools for capturing the nature of experiences, individual perspectives and opinions (Brotherson \& Goldstein, 1992:336; Krogh \& Lindsay, 1999:223; Krueger, 1988:47; Morse, 1996:467). The methodology will be described in terms of the participants, data collection and analysis as well as reliability and validity.

\section{Participants}

Community nurses employed by the Moretele Health District, a semi-rural and rural area situated in the North West Province (former Bophuthatswana), participated in this research. This Health District is viewed as a previously deprived area requiring ongoing Government support to uplift it and ensure equality of services. Despite this, the particular area is a good example of close collaboration between the Health District, which provides $\mathrm{PHC}$ and the Jubilee Hospital, which provides secondary health care. It is also relatively close to Pretoria where tertiary care, viz. traditional rehabilitation by therapists, is provided. This Health District is made up of a total of 25 clinics and 14 mobile points, which serve an estimated average of 4365 persons per day. The clinics differ in size, ranging from some with only two nurses serving approximately 30 people daily to some clinics with eight nurses serving 300 people daily.

Participants were either working in clinics or at the various mobile points in the area at the time when the research was conducted and nurses who were not working in a nursing capacity (e.g. only administratively), who were positioned at the Jubilee hospital (providing secondary care), who were between jobs or retired, were excluded. The qualifications of the nurses were not included as a selection criterion, so that it covered a whole range, from nursing assistants to professional nurses.

Background information on the participants in terms of their age, gender, nursing status and experience, is provided in Table 1.

\section{Data collection}

In order to obtain the quantitative data, the researcher and fieldworker visited all 25 clinics and 14 mobile points in the particular health district in order to complete the questionnaire. Table 2 provides a summary of the most important areas covered in the questionnaire, with specific reference to the motivation for inclusion. The category, type and number of each question in each category are also discussed.

All the nurses who were present on the day that the researcher visited the particular site (ranging from nursing assistants to professional nurses) were included. A total of 111 questionnaires were completed. This implies that $92 \%$ of the total population was surveyed (111 of 121 nurses employed in the Moretele Health District).

In order to obtain the qualitative data, 21 community nurses from this district who took part in an in-service training programme called "Nurses-in-Training" that meets monthly and receives talks on various nursingrelated topics, were involved. Due to the vast spread out nature of the district and the impracticality of closing clinics so that nurses could participate in the research, it was decided to include all the nurses who attended the first "Nurses-in-Training" programme for 2000 in the focus group. This resulted in two focus groups: one focus group with 10 , and the other with 11 participants. Literature suggests groups of $8-10$ participants (Frey \& Fontana, 1993:28). As a result of the commonalties that these nurses share and the fact that they mostly knew each other, rapport was quickly es 
Table 1: $\quad$ Background information on participants $(n=111)$

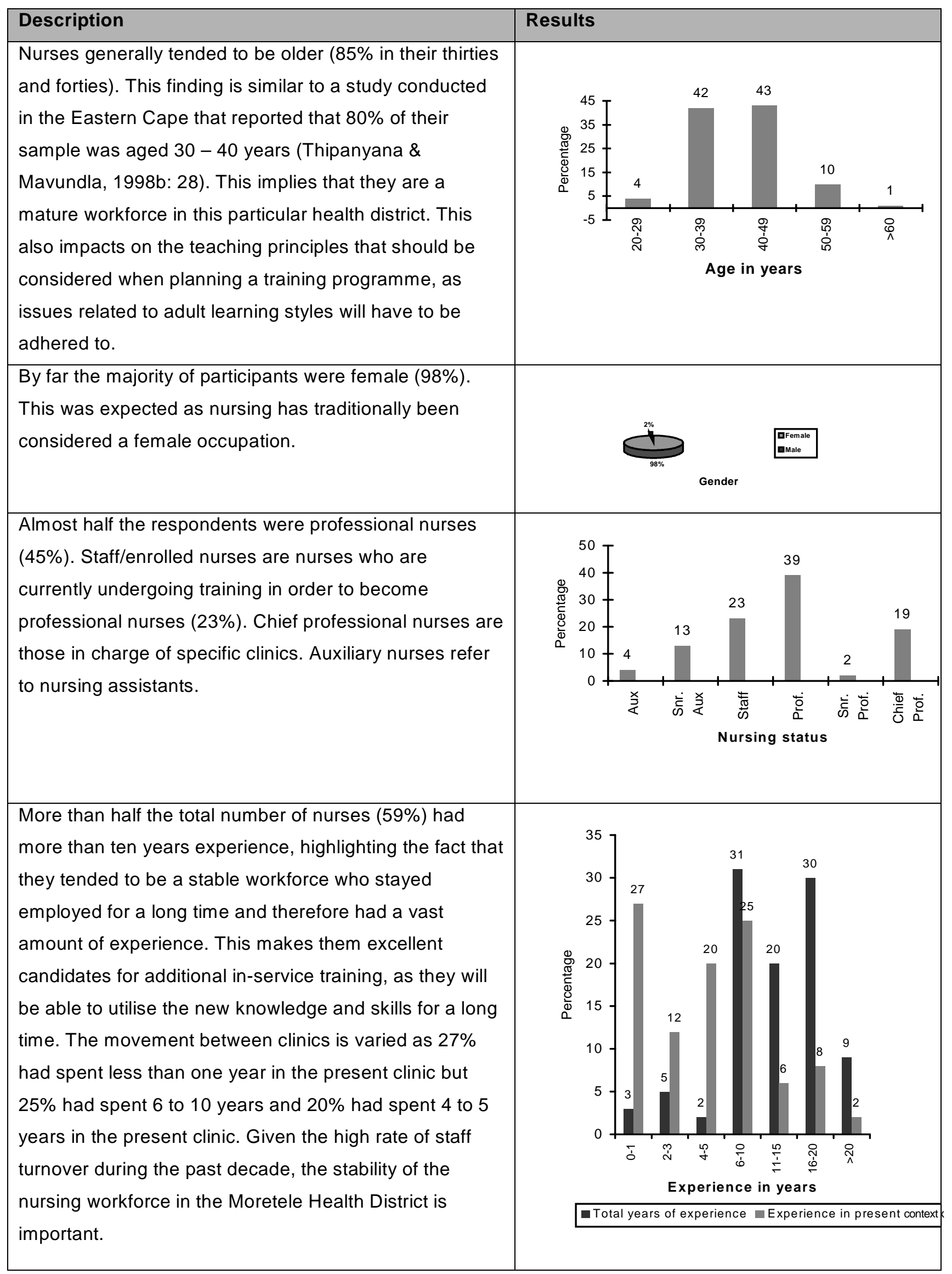


Table 2: Development of the questionnaire

\begin{tabular}{|c|c|c|c|c|}
\hline $\begin{array}{l}\text { Catego- } \\
\text { ry }\end{array}$ & $\begin{array}{l}\text { Ques- } \\
\text { tion }\end{array}$ & Question area & $\begin{array}{l}\text { Type of } \\
\text { question }\end{array}$ & Motivation \\
\hline $\begin{array}{l}\text { Biogra- } \\
\text { phic } \\
\text { data }\end{array}$ & $\begin{array}{l}1 \\
2 \\
3 \\
4 \\
5 \\
6\end{array}$ & $\begin{array}{l}\text { linic name } \\
\text { ender } \\
\text { irth date } \\
\text { ursing status } \\
\text { xperience as a } \\
\text { urse } \\
\text { xperience in } \\
\text { resent setting }\end{array}$ & $\begin{array}{l}\text { Five open- } \\
\text { ended } \\
\text { questions. } \\
\text { One close- } \\
\text { ended question } \\
\text { (gender) }\end{array}$ & $\begin{array}{l}\text { Clinic names were used for identification } \\
\text { purposes and to ensure that all clinics were } \\
\text { visited. Gender, birth date, nursing status, years } \\
\text { of experience as a nurse and experience in the } \\
\text { present setting were used for descriptive } \\
\text { purposes as all these factors could impact on the } \\
\text { type of responses provided. This information is } \\
\text { important for compiling a profile of the nurses as } \\
\text { these aspects impact on knowledge and skills as } \\
\text { well as on the type of services they provide. }\end{array}$ \\
\hline $\begin{array}{l}\text { Expo- } \\
\text { sure to } \\
\text { the } \\
\text { different } \\
\text { disability } \\
\text { types }\end{array}$ & 7 & $\begin{array}{l}\text { requency of } \\
\text { xposure to the } \\
\text { ifferent disability } \\
\text { ypes }\end{array}$ & $\begin{array}{l}\text { Close-ended } \\
\text { question with 5- } \\
\text { point Likert } \\
\text { scale }\end{array}$ & $\begin{array}{l}\text { Information was obtained regarding nurse's } \\
\text { exposure to the following disability types: } \\
\text { intellectual impairment, cerebral palsy (CP), } \\
\text { deafness, blindness, LNFS and an open } \\
\text { category for "other". Exposure was measured in } \\
\text { terms of frequency, and included the following } \\
\text { categories: never, every week, every } 2 \text { weeks, } \\
\text { every month and less than once a month. } \\
\text { Exposure is an important factor as this directly } \\
\text { impacts on perceptions and knowledge about a } \\
\text { specific phenomenon. }\end{array}$ \\
\hline $\begin{array}{l}\text { Serious- } \\
\text { ness of } \\
\text { different } \\
\text { disability } \\
\text { types in } \\
\text { the area }\end{array}$ & 8 & $\begin{array}{l}\text { nowledge about } \\
\text { he seriousness } \\
f \text { the different } \\
\text { isability types in } \\
\text { he area }\end{array}$ & $\begin{array}{l}\text { Close-ended } \\
\text { question with 5- } \\
\text { point Likert } \\
\text { scale }\end{array}$ & $\begin{array}{l}\text { Apart from all the different disability types (i.e. } \\
\text { intellectual impairment, cerebral palsy (CP), } \\
\text { deafness, blindness, LNFS and multiple } \\
\text { disabilities) categories described in the White } \\
\text { paper for the transformation of the health system } \\
\text { in South Africa (Government Gazette 17910, } \\
\text { 1997:24), as priority areas for children, namely } \\
\text { HIV/AIDS, Tuberculosis and chronic diseases, } \\
\text { e.g. asthma, were also included. Nurses were } \\
\text { asked whether they regarded these conditions as } \\
\text { very serious, serious, average, mild or as no } \\
\text { problem in their particular work context. This is a } \\
\text { crucial element in determining perceptions, as } \\
\text { nurses will have no desire to acquire skills and } \\
\text { knowledge in a particular area if they do not } \\
\text { regard this area as a serious problem. }\end{array}$ \\
\hline
\end{tabular}




\begin{tabular}{|c|c|c|c|c|}
\hline $\begin{array}{l}\text { Comfort } \\
\text { able- } \\
\text { ness in } \\
\text { handling } \\
\text { disability }\end{array}$ & 9 & $\begin{array}{l}\text { eflective } \\
\text { elf-rating of } \\
\text { omfortableness in } \\
\text { andling children } \\
\text { ith various types } \\
f \text { disability }\end{array}$ & $\begin{array}{l}\text { Close-ended } \\
\text { question with 4- } \\
\text { point Likert } \\
\text { scale to ensure } \\
\text { that the middle } \\
\text { category is not } \\
\text { selected }\end{array}$ & $\begin{array}{l}\text { The degree to which nurses feel comfortable in } \\
\text { handling the different disability types might be } \\
\text { used as a predictor of how they view their skills } \\
\text { and knowledge in this regard. It is assumed that } \\
\text { if nurses have the knowledge and skills to deal } \\
\text { with a child with a particular disability that they } \\
\text { would then feel comfortable in handling this child. } \\
\text { However, a disadvantage of self-evaluation is } \\
\text { that it is difficult to be objective and to accept } \\
\text { one's own strengths and weaknesses } \\
\text { (Bradshaw, 1989:108). }\end{array}$ \\
\hline $\begin{array}{l}\text { Type of } \\
\text { service } \\
\text { delivery }\end{array}$ & 10 & $\begin{array}{l}\text { ype of service } \\
\text { sually rendered } \\
\text { o children with } \\
\text { arious types of } \\
\text { isability }\end{array}$ & $\begin{array}{l}\text { Close-ended } \\
\text { question with 5- } \\
\text { point Likert } \\
\text { scale }\end{array}$ & $\begin{array}{l}\text { It is important to determine the type of service } \\
\text { provided to children with disabilities, i.e. direct } \\
\text { referral to hospital/therapists; direct referral to } \\
\text { schools; give advice or counsel parents and } \\
\text { refer; obtain case history, screen and refer or } \\
\text { interact with the child and provide guidelines to } \\
\text { handle the child without referral. This information } \\
\text { is important, as it is known that direct referral is } \\
\text { problematic in rural areas (due to limited referral } \\
\text { options, poverty and transport problems, little or } \\
\text { no feedback to the referring nurse, etc.). }\end{array}$ \\
\hline $\begin{array}{l}\text { Sensitivi- } \\
\text { ty and } \\
\text { aware- } \\
\text { ness }\end{array}$ & 11 & $\begin{array}{l}\text { wareness of the } \\
\text { eeds of children } \\
\text { ho receive } \\
\text { ervices }\end{array}$ & $\begin{array}{l}\text { One open- } \\
\text { ended question }\end{array}$ & $\begin{array}{l}\text { This question was included to obtain information } \\
\text { about the priority areas of service delivery as } \\
\text { seen by nurses. It was important to keep this as } \\
\text { an open-ended question in order to not miss out } \\
\text { any data that the researcher might have } \\
\text { overlooked in compiling the questionnaire. }\end{array}$ \\
\hline
\end{tabular}

tablished, so that the focus group was experienced as non-threatening. Each focus group was facilitated by a speech language therapist (SLT) with a primary interest in the severe disability field. It was aimed at determining nurses' perceptions and their exposure to CSDs as well as encouraging them to respond from their own experience. The researcher acted as one of these facilitators. English was used as the focus group medium as all nurses were conversant and comfortable with it. Both facilitators led the respective focus groups in a semi-structured discussion of three openended questions (Frey \& Fontana, 1993:36; Krueger, 1988:60), namely:

- How often do you see the primary caregivers of CSDs?
- Tell us about your experience.

- What do you think are the biggest problems these primary caregivers have?

- What can we do to help you to help the primary caregivers of CSDs better?

During the discussion the facilitators asked for clarification when some concepts were unclear or in cases where the data were open to misinterpretation (Bryman, 1994:5; Krefting, 1991:219). Nurses were also encouraged to take part actively, to share their wealth of experience, to understand that no comments would be regarded as "stupid" or "silly" and were assured that they would remain anonymous. Flexibility was allowed 
in terms of the sequence of questions so that facilitators were able to listen to the discussion, to observe and to respond to what they saw and heard. Structural coherence of the topic was thus maintained, increasing credibility (Krefting, 1991:217). In an attempt to enhance trustworthiness member checks were included, which entailed that the facilitators gave a short summary at the end of the discussion of each of the three questions. Participants were then asked whether they agreed, disagreed, or if any important issues raised had been overlooked (Hoffart, 1991:526). The two facilitators spent some time debriefing directly after the focus groups to discuss their interpretations in order to enhance trustworthiness (Peshkin, 1993:24). No areas that needed additional probing or clarification were noted. Debriefing is an important part of investigator triangulation and was included to heighten the credibility of the data obtained (Brotherson \& Goldstein, 1992:337; Kimchi, Polivka \& Stevenson, 1991:364365). Verbatim transcriptions of these two focus groups were made. Focus group 1 lasted 58 minutes and Focus group 2 lasted 67 minutes.

\section{Data analysis}

For the analysis of the quantitative data descriptive statistics (frequency distribution counts and percentages) were used, implying that all variable values were listed and counted each time they occurred (Babbie \& Mouton, 2001:460). In addition, contingency tables were created as they indicate the relationship between sets of nominal data (e.g. determining the relationship between exposure to the different disability types and how comfortable nurses felt in dealing with these children). The Pearson Chi-square test was then used to determine the significance of this relationship.

Regarding the qualitative data, the researcher delineated themes from each of the two focus groups and came to some tentative conclusions. Transcriptions were then handed to the other focus group facilitator and she was also asked to delineate themes (peer debriefing). Care was taken to avoid "coding fetishism" where coding becomes a mechanical process of labelling involving obsessive and unnecessary details (Webb, 1999:325). Rather, coding was seen as part of the whole analytic process that also involves theoretical perspectives and interpretations. When two re- searchers separately code and then cross-check data, the issue of analytic stability comes to the foreground (Brotherson \& Goldstein, 1992:338). In order to address this, both researchers received a set of coding guidelines pertaining to the content and the analytic procedure, e.g. the initial questions that were appropriate as well as the decision rules for determining the categories. Following the development of the themes the two facilitators met to review the theme analysis with a request for verification, correction, clarification and/or elaboration of tentative conclusions drawn from the data analysis. This process is essential in order to ensure the credibility of the data (Krueger, 1988:60). Apart from obtaining only significant and consistent themes in the data it is also rich in providing illustrative examples. In order to not fragment, decontextualise and/or misinterpret data, it was crucial to go back to the complete text frequently (Webb, 1999:327).

\section{Validity and reliability}

Regarding the quantitative data (questionnaire) the following factors were taken into consideration:

- Where possible, structured, close-ended questions were used to accommodate time constraints and to assist the auxiliary and staff nurses whose literacy skills were not as well developed as those of the professional nurses. Providing them with a choice of possibilities from which they had to select one acted as a prompt. This enabled the researcher to obtain an idea of what they knew, not merely of what they were able to write and spell. A pilot study was conducted to test the applicability of the questionnaire and to ensure that relevant answers were not overlooked (Leedy, 2001:204).

- Some questions, e.g. Question 11 "In your opinion, what are the things that most children that you see, need?' was asked in openended format, so that the participants were not guided in a specific direction, and also to allow them to answer in their own words.

- Likert scales did not include more than five options (so that the options did not become visually overwhelming and so that participants 
could remember the options (Babbie \&

Mouton, 2001:153).

- Items were mostly short e.g. Question 8 "How serious are the following problems in your opinion?" and care was taken to ensure that each question dealt with only one concept (Babbie \& Mouton, 2001:234).

- Care was taken to avoid any biased or leading questions, jargon and other difficult terminology, and also to ensure the clarity of the questions, so that all the participants understood the same concepts with the vocabulary used (Bynner \& Stribley, 1979:141; Mertens, 1998:115).

- An attempt was made to keep the questionnaire as short as possible to ensure that participants did not lose interest and/or become fatigued resulting in the omission of important information (Leedy, 2001:206).

- Meticulous care was taken with the visual appearance of the questionnaire. Questions were all numbered, organised in logical sequence and did not have too many items per page. Care was taken to ensure correct spelling and grammar throughout (Mertens, 1998:115117).

- Clear, brief instructions to guide the participants were included at the top of the questionnaire. They were encouraged to complete all questions, as incomplete responses would impact on the reliability of the data (Leedy, 2001:207).

In qualitative research, on the other hand, the terms reliability and validity cannot be used, as the nature of the data is different from that of quantitative data. Instead, a new set of criteria, developed for and fit for qualitative research should be used, one of which is the concept "trustworthiness" (Cutcliffe \& McKenna, 1999:375; Kirk \& Miller, 1986:23). In the present research attempts were made to increase the trustworthiness of the data through the use of specific techniques, which are displayed in Table 3 (Brotherson \& Goldstein, 1992:336-338; Cutcliffe \& McKenna, 1999:376-379; Kimchi, Polivka \& Stevenson, 1991:364-366; Klopper, 1995:25-28; Krefting,
1991:215-221; Krogh \& Lindsay, 1999:227; Krueger, 1993:126). Both the qualitative terms and better-known quantitative terms are also included in this table. (Table 3 starts on next page.)

\section{ETHICAL CONSIDERATIONS}

Permission to perform the study was obtained from the relevant authorities. All participants from clinics in the given health district who were able to participate, were included. Data collection was conducted within the current structures for training, i.e. the existing "Nurses in Training" group to minimalise any disruption to the general treatment of patients. All participants were informed of the aims and nature of the research and gave consent that the information could be used. To protect the identity of the participants no identifying information is provided.

\section{RESULTS AND DISCUSSION}

Results revealed the nurses' current exposure to CSDs, their rating of the seriousness of various health conditions as well as their comfortableness in dealing with CSDs across the different disability types. Results are shown in Table 4. (Table 4 follows table 3.)

In order to further explore the latter aspect, contingency tables were created to correlate the relationship between exposure to the different disability types and how comfortable nurses felt in dealing with these children. The Pearson Chi-square test was administered to all the categories. Results are shown in Table 5. (Table 5 is on page 45.)

From Table 5 it is clear that intellectual impairment and little or no functional speech (LNFS), which implies a severe communication disorder, proved to be statistically significant, and therefore further testing was done. These results are shown in Table 6. (Table 6 is on page 45.) 
Table 3: Increasing trustworthiness of the research during focus groups with community nurses

\begin{tabular}{|c|c|c|}
\hline Strategy & Technique & How technique was addressed in present research \\
\hline $\begin{array}{l}\text { Credibility } \\
\text { What is the } \\
\text { truth-value of } \\
\text { the research? }\end{array}$ & $\begin{array}{l}\text { Prolonged, } \\
\text { sustained } \\
\text { engagement } \\
\text { (Spencer, } \\
\text { 1993:120) }\end{array}$ & $\begin{array}{l}\text { The researcher has been involved in the Moretele Health District for } \\
\text { approximately eight years. Before conducting the research, one month was } \\
\text { spent observing the clinics in an informal way. This prolonged engagement } \\
\text { ensured trust between the researcher and the participants, providing her with } \\
\text { the opportunity to become entrenched in the culture and work ethics of the } \\
\text { nurses and aided in the removal of certain misconceptions (e.g. the number } \\
\text { of CSDs seen by nurses). }\end{array}$ \\
\hline $\begin{array}{l}\text { Known as } \\
\text { internal } \\
\text { validity in } \\
\text { quantitative } \\
\text { research. }\end{array}$ & $\begin{array}{l}\text { Persistent } \\
\text { observation } \\
\text { of } \\
\text { phenomena } \\
\text { in various } \\
\text { contexts and } \\
\text { situations. }\end{array}$ & $\begin{array}{l}\text { All clinics in the given health care district was visited, not only a select few. } \\
\text { Disability and the provision of services at PHC level were not only viewed } \\
\text { from the nurses' perspective, but information was also obtained from the } \\
\text { health care district managers and primary caregivers of children with severe } \\
\text { disabilities. }\end{array}$ \\
\hline & $\begin{array}{l}\text { Triangulation } \\
\text { Data } \\
\text { triangulation } \\
\text { at person } \\
\text { level } \\
\text { Method } \\
\text { triangulation } \\
\text { Investigator } \\
\text { triangulation } \\
\\
\text { Analysis } \\
\text { triangulation } \\
\text { Multiple } \\
\text { triangulation }\end{array}$ & $\begin{array}{l}\text { A number of different triangulation types were used for the purpose of the } \\
\text { research. They are as follows: } \\
\text { Person triangulation involved the collection of data on individual levels } \\
\text { (questionnaires) and on group level (focus groups). Data collected from one } \\
\text { source was used to validate data from the other source. } \\
\text { A between-methods triangulation was used as the research employed } \\
\text { qualitative data (obtained from the focus groups) as well as quantitative data } \\
\text { (obtained from questionnaires). } \\
\text { Researchers from diverse backgrounds (Nurse, SLP, AAC specialist) with } \\
\text { experience in qualitative research were included in the research. This } \\
\text { enhanced the quality of data as each researcher brought her own expertise } \\
\text { to the research. } \\
\text { Both qualitative and quantitative approaches were applied in analysing } \\
\text { the data. By comparing the results of these two techniques the researcher } \\
\text { was able to note similar patterns and thus verify findings. } \\
\text { Multiple triangulation occurs when more than one type of triangulation is } \\
\text { used, intensifying the advantages of the different types of triangulation, } \\
\text { further validating the findings and obtaining a more comprehensive and } \\
\text { satisfactory sense of the phenomenon. The present research achieved this. }\end{array}$ \\
\hline
\end{tabular}




\begin{tabular}{|c|c|c|}
\hline & $\begin{array}{l}\text { Peer group } \\
\text { examinations } \\
\text { and } \\
\text { discussions }\end{array}$ & $\begin{array}{l}\text { Two independent researchers involved in PhD studies with experience in } \\
\text { qualitative research but diverse backgrounds (nursing and speech-language } \\
\text { pathology) were involved in order to assist with the exploration of concepts } \\
\text { and the analysis of data. This provided the researcher with the means to } \\
\text { discuss insights and problems, to "test' ideas regarding certain aspects and } \\
\text { also to prevent personal bias. This bias can be attributed not only to the } \\
\text { researcher's own culture, background, interest, etc. but could also arise from } \\
\text { the prolonged engagement in the particular community. These peer } \\
\text { discussions also led to deeper reflexive analysis of the data. }\end{array}$ \\
\hline & $\begin{array}{l}\text { Member } \\
\text { checking }\end{array}$ & $\begin{array}{l}\text { This is one of the most important aspects of ensuring credibility. After } \\
\text { themes were developed and the data analysed, results were presented to } \\
\text { the participants to ensure the correctness of conclusions. It provided nurses } \\
\text { with the opportunity to correct factual mistakes and to volunteer new } \\
\text { information, and also provided the researcher with the opportunity to record } \\
\text { the nurses' reactions after seeing the data in the new format. Cutcliffe and } \\
\text { McKenna (1999:376) highlighted the importance of using the actual words of } \\
\text { the participants as they recognise their own words and respond better, as it } \\
\text { has specific meaning for them. }\end{array}$ \\
\hline & $\begin{array}{l}\text { Stakeholder } \\
\text { review }\end{array}$ & $\begin{array}{l}\text { Stakeholders were involved throughout the process to assist with reviewing } \\
\text { the findings, clarifying points of interpretative or descriptive disagreement, } \\
\text { prioritising unresolved issues and collecting information on those issues. }\end{array}$ \\
\hline \multirow{3}{*}{$\begin{array}{l}\text { Transferabil- } \\
\text { ity } \\
\text { How } \\
\text { applicable } \\
\text { will the data } \\
\text { be in other } \\
\text { contexts or } \\
\text { other partici- } \\
\text { pants? } \\
\text { Known as } \\
\text { external } \\
\text { validity in } \\
\text { quantitative } \\
\text { research }\end{array}$} & $\begin{array}{l}\text { Selection of } \\
\text { information } \\
\text { about the } \\
\text { phenomena } \\
\text { by a panel of } \\
\text { experts }\end{array}$ & $\begin{array}{l}\text { The researcher attempted not to work in isolation, and had frequent } \\
\text { meetings with stakeholders, experts in the nursing and disability fields, } \\
\text { government representatives as well as primary caregivers of CSDs } \\
\text { throughout the whole research project. Examples include the assistance of } \\
\text { nursing experts when the questionnaire was drawn up, discussions with } \\
\text { disability and nursing experts in determining applicable questions for the } \\
\text { focus groups. }\end{array}$ \\
\hline & $\begin{array}{l}\text { Use of } \\
\text { multiple } \\
\text { cases or } \\
\text { groups }\end{array}$ & $\begin{array}{l}\text { Two focus groups were used to ensure rich descriptive data and to enhance } \\
\text { the transferability of the data. Results from the two groups were compared } \\
\text { and this was also compared with data obtained from the questionnaire. }\end{array}$ \\
\hline & $\begin{array}{l}\text { Ensure } \\
\text { representati- } \\
\text { veness of } \\
\text { participants } \\
\text { (Spencer, } \\
\text { 1993:125) }\end{array}$ & $\begin{array}{l}\text { The background information of the participants for the focus groups was } \\
\text { obtained from a short questionnaire. This was then compared with the } \\
\text { available demographic information for the whole group in order to ensure } \\
\text { representativeness. }\end{array}$ \\
\hline
\end{tabular}




\begin{tabular}{|c|c|c|}
\hline & $\begin{array}{l}\text { Look at the } \\
\text { data rather } \\
\text { than the topic } \\
\text { of } \\
\text { investigation }\end{array}$ & $\begin{array}{l}\text { It is important to determine whether the data obtained can be seen as typical } \\
\text { or atypical of the phenomenon under investigation. This is briefly described } \\
\text { in the results section. }\end{array}$ \\
\hline \multirow[t]{4}{*}{$\begin{array}{l}\text { Dependabil- } \\
\text { ity } \\
\text { How } \\
\text { consistent } \\
\text { are the } \\
\text { results? Can } \\
\text { the research } \\
\text { be repeated? }\end{array}$} & $\begin{array}{l}\text { Indirect } \\
\text { method } \\
\text { Look at } \\
\text { internal and } \\
\text { external } \\
\text { validity } \\
\text { measure- } \\
\text { ments }\end{array}$ & $\begin{array}{l}\text { The above-mentioned discussion on credibility and transferability is } \\
\text { important for this section, as Krefting (1991:221) states that no validity is } \\
\text { possible without reliability (and thus no credibility without dependability). A } \\
\text { demonstration of the former is sufficient to establish the latter. }\end{array}$ \\
\hline & $\begin{array}{l}\text { Direct } \\
\text { method } \\
\text { Triangulation }\end{array}$ & $\begin{array}{l}\text { This method and its application in the current research has already been } \\
\text { discussed in detail. }\end{array}$ \\
\hline & $\begin{array}{l}\text { Direct } \\
\text { method } \\
\text { Stepwise } \\
\text { replication }\end{array}$ & $\begin{array}{l}\text { In qualitative research the researcher always aims to provide a "thick" or } \\
\text { "rich" description of the context. Rigour was applied in describing the } \\
\text { context, how data was obtained, analysed (i.e. the development of themes) } \\
\text { and interpreted. The methodology should be explicit enough for an } \\
\text { independent researcher to repeat. }\end{array}$ \\
\hline & $\begin{array}{l}\text { Direct } \\
\text { method } \\
\text { Dependability } \\
\text { audit }\end{array}$ & $\begin{array}{l}\text { A researcher independent from the present research was asked to establish } \\
\text { how dependable data presented is, and to determine the accuracy of the } \\
\text { data (including analysis and recommendations). }\end{array}$ \\
\hline $\begin{array}{l}\text { Confirmability } \\
\text { How neutral } \\
\text { is the } \\
\text { research? } \\
\\
\text { Known as } \\
\text { objectivity in } \\
\text { qualitative } \\
\text { research. }\end{array}$ & $\begin{array}{l}\text { Confirmability } \\
\text { audit / } \\
\text { Process audit } \\
\text { trial on } \\
\text { described } \\
\text { chain of } \\
\text { events. }\end{array}$ & $\begin{array}{l}\text { An independent knowledgeable researcher with experience in the field of } \\
\text { qualitative research was asked to evaluate the degree in which the research } \\
\text { process, including the raw data, data reduction and analysis products } \\
\text { (condensed notes and qualitative summaries), data reconstruction (thematic } \\
\text { categories), findings, interpretations and recommendations follow acceptable } \\
\text { research practice. This researcher (the "auditor") stood completely neutral to } \\
\text { the research. It should be emphasised that neutrality is not seen as a way to } \\
\text { avoid "contamination". Rather the researcher's characteristics, attitudes and } \\
\text { feelings are recognised as influencing the research and hence made explicit. }\end{array}$ \\
\hline
\end{tabular}


Table 4: Nurses' exposure to CSDs and their perceptions regarding seriousness and comfortableness in handling it $(n=111)$

\begin{tabular}{|l|}
\hline Description \\
\hline According to the Department of Health \\
(Government Gazette 17910, 1997:23-24) the \\
following health issues should receive the highest \\
priority: namely tuberculosis (TB), HIV/AIDS, \\
chronic diseases (e.g. asthma) and violence and \\
trauma. These health issues together with \\
intellectual impairment (II) were reported as being \\
the most serious problems confronting nurses in \\
the respective clinics.
\end{tabular}

This concern is echoed by the World Health Organisation (WHO), who took the unprecedented step and declared TB a global emergency due to their grave concern about the modern TB epidemic (WHO, 2000:1). This document further states that more than 1.5 million TB cases per year occur in sub-Saharan Africa. This number is rapidly increasing as a result of the lethal HIV-TB combination, each speeding up the other's progress. TB is a leading cause of death among people who are HIV-positive and accounts for $15 \%$ of AIDS deaths worldwide (WHO, 2000:2). In Africa, HIV is the most important factor determining the increased incidence of TB the past ten years. Other factors that contribute to the worsening impact of TB include malnourishment, the breakdown of health services in many areas, poverty and the emergence of multi-drug resistant TB.

Weighted frequencies indicate that there were no significant differences in the nurses' level of comfort in dealing with children with different types of disabilities, i.e. they did not feel more uncomfortable with a child with intellectual impairment (II) than with a child with CP.

\section{Results}

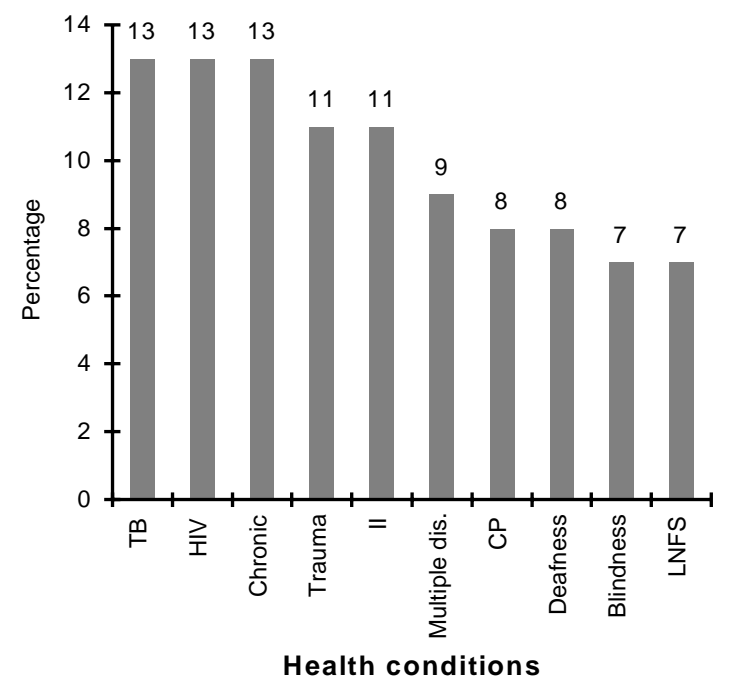

Health conditions

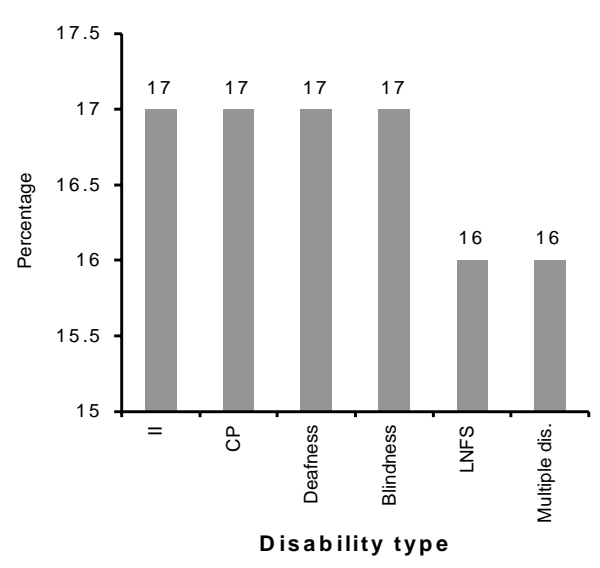




More than half the total number of nurses (59\%)
had more than ten years experience, highlighting
the fact that they tend to be a stable workforce that
stayed employed for a long time and because of
this had a vast amount of experience. This makes
them excellent candidates for additional in-service
training, as they will be able to utilise the new
knowledge and skills for a long time. The
movement between clinics is varied as $27 \%$ had
spent less than one year in the present clinic but
$25 \%$ had spent 6 to 10 years and $20 \%$ had spent 4
to 5 years at the present clinic. Given the high rate
of staff turnover during the past decade, the
stability of the nursing workforce in the Moretele
Health District is important.

Table 5: Significance of exposure to disability vs. comfortableness in handling disability

\begin{tabular}{|c|c|c|}
\hline Disability type & Chi-square value & Significance: $p<0,05$ \\
\hline Intellectual impairment & 0,024 & $0.024^{\star}$ \\
\hline Cerebral palsy & 0,159 & 0.159 \\
\hline Deafness & 0,252 & 0.252 \\
\hline Blindness & 0,352 & 0.352 \\
\hline LNFS & 0,004 & $0.004^{\star}$ \\
\hline
\end{tabular}

Table 6: Frequency of exposure to intellectual impairment vs. comfortableness in handling it

\begin{tabular}{|l|l|l|l|l|}
\hline Exposure & Description & Uncomfortable & Comfortable & Total \\
\hline Never & Frequency & $\mathbf{1}$ & $\mathbf{1 5}$ & $\mathbf{1 6}$ \\
& Percentage & 1.0 & 13.5 & 14.5 \\
& Row \% & 6.3 & 93.7 & \\
& Column \% & 2.8 & 20.0 & \\
\hline Once a week to & Frequency & $\mathbf{1 7}$ & $\mathbf{3 7}$ & $\mathbf{5 4}$ \\
once a month & Percentage & 15.3 & 33.3 & 48.6 \\
& Row \% & 31 & 68.5 & \\
& Column \% & 47.2 & 49.3 & \\
\hline Less than once a & Frequency & $\mathbf{1 8}$ & $\mathbf{2 3}$ & $\mathbf{4 1}$ \\
& Percentage & 16.2 & 20.7 & 36.9 \\
& Row \% & 43.9 & 56.1 & \\
& Column \% & 50.0 & 30.7 & \\
\hline Total & Frequency & $\mathbf{3 6}$ & $\mathbf{7 5}$ & $\mathbf{1 1 1}$ \\
& Percentage & 32.5 & 67.5 & $100 \%$ \\
\hline
\end{tabular}

This $2 \times 3$ contingency table (Table 6 ) clearly shows that the majority of nurses $(67.5 \%)$ felt comfortable in handling children with intellectual impairment. Only a small number of nurses indicated that they had never seen children with intellectual impairment (16 nurses). This is important, as intellectual disability comprises $3 \%$ of the total $12,7 \%$ of disabled people making it the largest disability type (Year of the Disabled Persons Report, 1986:15). In addition, the role of community nurses in the rehabilitation of children with intellectual impairments has become more prominent in recent years (Alant, 1998:18). This table also indicates that despite their exposure to children with intellectual impairment all the nurses felt more comfortable than uncomfortable in handling these children. However, the nurses who had never seen children with intellectual impairment were notably the group who felt the most comfortable in handling them (93.7\%). This might be due to the fact that they were unaware of the potential problems and issues of dealing with these children.

The second disability category that indicated significance on the Pearson Chi-square test was children with LNFS. Data for this group is shown in Table 7. 
Table 7: Frequency of exposure to children with LNFS vs. comfortableness in handling them

\begin{tabular}{|c|c|c|c|c|}
\hline Exposure & Description & Uncomfortable & Comfortable & Total \\
\hline Never & \begin{tabular}{|l|} 
Frequency \\
Percentage \\
Row \% \\
Column \%
\end{tabular} & \begin{tabular}{|l|}
16 \\
14.4 \\
27.6 \\
34.0
\end{tabular} & \begin{tabular}{l|l|}
42 & \\
37.8 & \\
72.4 & \\
65.6 &
\end{tabular} & $\begin{array}{l}58 \\
52.2\end{array}$ \\
\hline $\begin{array}{l}\text { Once a week to } \\
\text { once a month }\end{array}$ & \begin{tabular}{|l|} 
Frequency \\
Percentage \\
Row \% \\
Column \%
\end{tabular} & \begin{tabular}{|l|l|}
11 \\
9.9 \\
57.9 \\
23.4
\end{tabular} & \begin{tabular}{l|l}
8 \\
7.2 \\
42.1 \\
12.5
\end{tabular} & $\begin{array}{l}\mathbf{1 9} \\
17.1\end{array}$ \\
\hline $\begin{array}{l}\text { Less than once a } \\
\text { month }\end{array}$ & $\begin{array}{l}\text { Frequency } \\
\text { Percentage } \\
\text { Row \% } \\
\text { Column \% }\end{array}$ & $\begin{array}{l}20 \\
18.0 \\
58.8 \\
42.6\end{array}$ & \begin{tabular}{l|}
$\mathbf{1 4}$ \\
12.6 \\
41.2 \\
21.9
\end{tabular} & $\begin{array}{l}34 \\
30.6\end{array}$ \\
\hline Total & \begin{tabular}{|l|} 
Frequency \\
Percentage
\end{tabular} & $\begin{array}{l}47 \\
42.3\end{array}$ & $\begin{array}{l}64 \\
57.6\end{array}$ & $\begin{array}{l}\mathbf{1 1 1} \\
100 \%\end{array}$ \\
\hline
\end{tabular}

This $2 \times 3$ contingency table (Table 7 ) indicates that the majority of nurses $(57.6 \%)$ felt comfortable in handling children with LNFS. The difference between the two groups $(42.3 \%$ vs. $57.6 \%)$ is smaller than the similar difference when viewing intellectual impairment in Table 6 (32.5\% vs. $67.5 \%)$. Children with LNFS are also a phenomenon that nurses do not see as frequently, as $52.2 \%$ noted that they had never seen a child with LNFS. Of this $52.2 \%$ substantially more nurses felt comfortable $(72.4 \%)$ rather than uncomfortable $(27.6 \%)$ in handling these children. However, once they were exposed to these children they became more uncomfortable in handling them, implying that even very infrequent The last section of the quantitative data relates to the type of service delivery and the needs of the CSDs as perceived by the nurses. Results are shown in Table 8. Table 8 follows on next page.

From Table 8 it is clear that the services to CSDs and their primary caregivers mostly entail direct referral, irrespective of the disability type. This is an important factor, as it was noted during the focus groups that the level of compliance with referral is low, as the primary caregivers of CSDs often do not have the necessary resources (e.g. financial constraints and transport difficulties). This correlates with observations from a study conducted in the Eastern Cape which also reported on the prominence of transport issues (Thipanyana \& Mavundla, 1998a:23). The sustainability of this type of service delivery is therefore questionable indicating the need to train community health by providing appropriate knowledge and skills so that direct service delivery to this population becomes feasible. According to Musholt (1995:307) this type of training should be transdisciplinary in nature so that community nurses can start acting as generalists as they need to draw on many resources to provide quality care. This is confirmed in the nurses' evaluation of what CSDs and their primary caregivers need. Apart from schools (22\%), the most pressing issues were trained professionals $(14 \%)$ and good parental care (14\%) that could be achieved through parent training programmes.

Regarding the qualitative data, a summary of the themes delineated from the two independent focus groups is provided in Appendix A. Five major themes crystallised, namely the nurses' perception of problems experienced by primary caregivers of CSDs, how nurses perceive their role regarding disability and the type of services they currently provide, problems they experience, their own experiences regarding CSDs and, finally, what they need in order to enhance their service delivery. Regarding problems experienced by primary caregivers aspects such as disempowerment (including a lack of knowledge, poor parenting skills, poverty, limited resources, unemployment and illiteracy), external influences (religion, culture and tradition, family and community), emotional problems (ranging from denial to anger) and the impact (e.g. a loss of status in the community) were mentioned. These findings are in accordance with literature which reports that community nurses often lack the necessary information and training to meet the unique health care needs of people with disabilities (Musholt, 1995:303). Nurses perceived their current role mostly as obtaining a casehistory, conducting a physical examination, detecting the problem, conducting health promotion and coordinating community-based rehabilitation (CBR) activities, treatment of minor medical ailments, referral and follow-up. These are also the traditional roles ascribed to nurses in the literature (Thomas, 1999:734). However, nurses acknowledged that in practice followups are not done and that most of the service delivery is based on referral, indicating a disagreement between policy and practice. They spoke spontaneously about the problems they encountered in the workplace, despite the fact that this information was not probed. This included aspects such as feelings of inadequacy due to the fact that they do not know how to handle primary caregivers of CSDs, depression, attitudinal barriers due to limited staff and time constraints and the fact that no follow-ups are done. Regarding their experiences it 
Table 8: Service delivery and needs of CSDs as perceived by nurses

\begin{tabular}{|c|c|}
\hline Description & Results \\
\hline $\begin{array}{l}\text { As expected, direct referral is the type of service most } \\
\text { frequently provided to CSDs, varying from referral to a } \\
\text { hospital, a specialist, a therapist, a school, a social } \\
\text { worker, etc., irrespective of the disability type. } \\
\text { Noticeably lower are cases where nurses perform } \\
\text { some direct service (e.g. counselling, advice, } \\
\text { screening and obtaining a case history) before referral. } \\
\text { Finally, services that include some hands-on service, } \\
\text { e.g. talking to the child, organising a wheelchair, giving } \\
\text { prescribed treatment or conducting home visits have } \\
\text { the lowest frequency. Although referral is seen as an } \\
\text { important function of community nurses (Thomas, } \\
\text { 1999:735) this becomes problematic in cases where } \\
\text { the services that people are referred to, are not easily } \\
\text { accessible, e.g. rural areas (Thipanyana \& Mavundla, } \\
\text { 1998a: } 22 \text { ). These findings are indicative of the fact } \\
\text { that nurses need knowledge and hands-on skills in } \\
\text { order to equip them to handle CSDs and their primary } \\
\text { caregivers in a more effective and efficient way. }\end{array}$ & 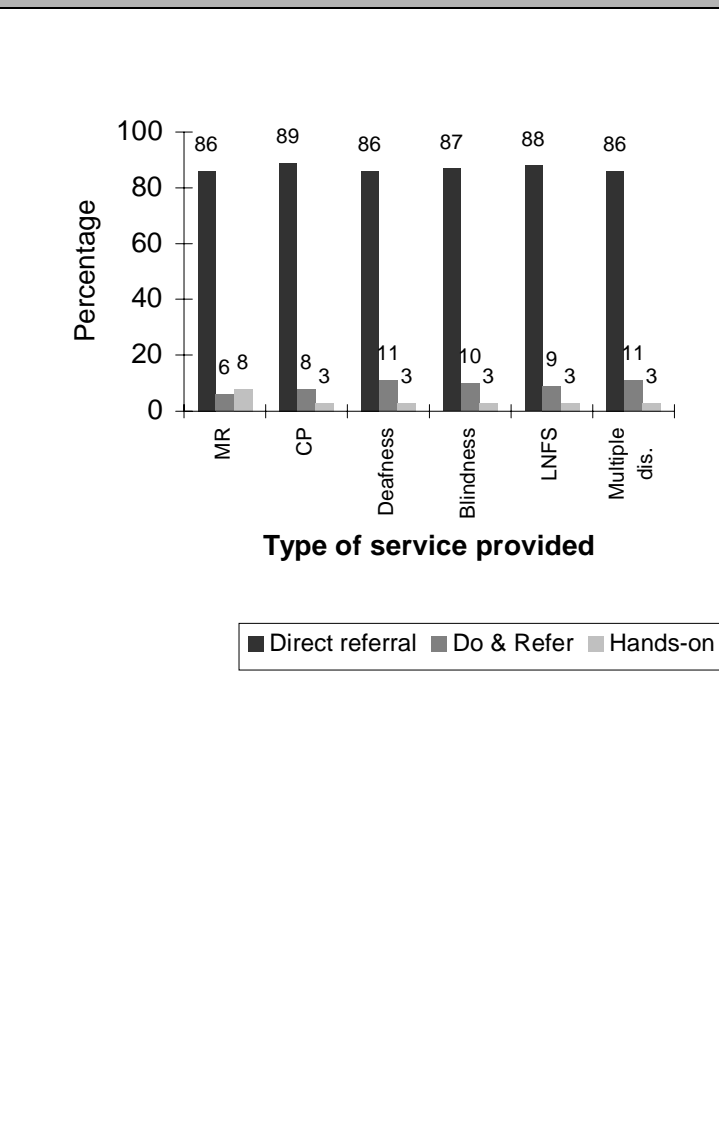 \\
\hline $\begin{array}{l}\text { A wide range of needs was identified. Nurses } \\
\text { perceived the need for a school to be the most } \\
\text { pressing for CSDs, followed by the need for trained } \\
\text { and skilled people to work with these children (14\%) } \\
\text { and more effective parental care that emphasises love } \\
\text { and care through the training of the primary caregivers } \\
\text { (14\%). The latter two aspects have also been } \\
\text { mentioned in the literature as pressing needs for CSDs } \\
\text { (Alant, 1998:20). }\end{array}$ & 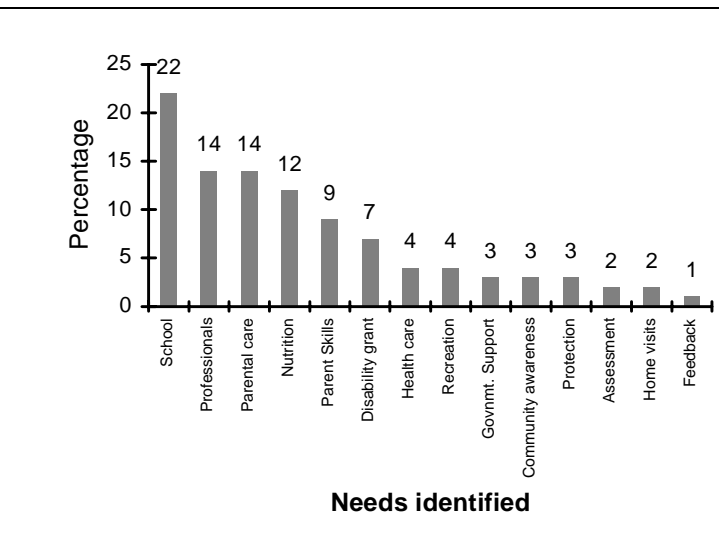 \\
\hline
\end{tabular}

was noted that their exposure varied. Although exposure was limited in some instances, the impact was high as most nurses could recall details about the CSDs, even when they had seen them more than a year ago. In addition, it was interesting to note how many CSDs are identified informally (e.g. neighbours inform nurses). When asking nurses what they required to enhance their service delivery it became clear that knowledge (education), skills, a positive attitude and raising community awareness were high priorities.

\section{LIMITATIONS OF THE RESEARCH}

- This study was conducted in a particular geographical area, namely the Moretele Health District, which is a semi-rural and rural area. Findings can therefore not be generalised to all PHC clinics. 
- English was used as the medium for data collection as all nurses reported that they felt proficient in using it. However, the richness of the data provided may have been enhanced had the study been conducted in the nurses' various mother tongues.

- Limited available research information regarding this particular topic exists for the South African context, and therefore the researcher had to rely on information obtained from other developing countries.

\section{IMPLICATIONS FOR FURTHER RE- SEARCH}

The results from both the quantitative and qualitative data have definite implications for service delivery to CSDs and their primary caregivers. Data clearly indicated that nurses felt inadequate about the way in which they handle CSDs and their primary caregivers and that they required more knowledge and skills that would in turn have a positive impact on their attitudes. It was also evident that nurses are well aware of CSDs and their primary caregivers' problems and that they are trusted by primary caregivers regarding discussions of their personal problems. This would make the nurses ideally suited to provide training to primary caregivers of CSDs so that they would be able to stimulate their own children. It was also clear that many primary caregivers in the Moretele Health District have poor parenting skills and that nurses would like to educate them. Furthermore, there are limited resources in the area, making appropriate referrals difficult. This might impact on the poor feedback that nurses receive (primary caregivers probably do not take their children to the referred places due to poverty, transport issues, etc.). This makes it clear that the training of nurses should focus on equipping nurses to train these primary caregivers so that their CSDs can remain in the community and that they do not have to move away.

It is therefore recommended that a specific training programme should be developed to meet these identified needs by equipping community nurses with the knowledge and skills to provide training and support to the primary caregivers of CSDs, so that the rehabilitation process can begin (Bornman, 2001:1-6). A training programme of this nature should have particular features in order to make it ideally suited to the South
African context. Firstly, it should incorporate the principles of adult learning (e.g. the use of a problem-based format and interactive teaching which would ideally include role-play, group discussions and video observations) as the needs analysis indicated that the participants were a mature group of learners. Secondly, the training programme should be relevant to the communication needs of children with severe disabilities as no similar kits exist that can address this need at a primary health care level.

\section{REFERENCES}

ALANT, E 1998: Augmentative and alternative communication: The role of community nurses in the rehabilitation of people with severe disabilities. Curationis, 21(2):17-21.

BABBIE, E \& MOUTON, J 2001: The practice of social research. Cape Town: Oxford University Press Southern Africa.

BORNMAN, J \& ALANT, E 1997: A school-based demographic survey of non-speaking children's communication and functional literacy skills. South African Journal of Education, 17(1):1520.

BORNMAN, J 2001: The development of a primary level communication protocol for children with severe disabilities. Pretoria: University of Pretoria (PhD in AAC dissertation).

BRADSHAW, PL 1989: Educating Adults. (In: Bradshaw, PL ed. 1989: Teaching and assessing in the clinical nursing practice. New York: Prentice-Hall).

BROTHERSON, MJ \& GOLDSTEIN, BL 1992: Quality design of focus groups in early childhood special education research. Journal of Early Intervention, 16(4):334-342.

BRYMAN, A 1994: The Mead/Freeman controversy: Some implications for qualitative researchers. (In: Burgess, RG ed, 1994: Studies in qualitative methodology: Issues in qualitative research. Volume 4. Middlesex: Jai Press Incorporated).

BURD, L; HAMMES, K; BORNHOEFT, DM \& FISHER, W 1988: A North Dakota prevalence study of nonverbal school-age children. Language Speech and Hearing Services in Schools, 19(4):371-383.

BYNNER, J \& STRIBLEY, KM 1979: Social research: Principles and procedures. London: Longman Group Ltd.

CHAPMAN, L \& WARE, J 1999: Challenging traditional roles and perceptions: Using a transdisciplinary approach in an inclusive mainstream school. Support for Learning, 14(3):104-109.

CLARK, MJ 1996: Nursing in the community; $2^{\text {nd }}$ ed. Stamford: Appleton \& Lange.

CUTCLIFF, JP \& MCKENNA, HP 1999: Establishing the credibility of qualitative research findings: The plot thickens. Journal of 
Advanced Nursing, 30(2):374-380.

DEPARTMENT OF HEALTH, 1999: The primary health care package for South Africa - A set of norms and standards. Pretoria: Department of Health.

FREY, JH, \& FONTANA, A 1993: The group interview in social research. (In: Morgan, DL ed. 1993: Successful focus groups. Advancing the state of the art. Newbury: Sage Publications).

GOVERNMENT GAZETTE NO 17910 1997: White paper for the transformation of the health system in South Africa. No 17910. Vol. 382. Pretoria: Government Printers.

HOFFART, N 1991: A member check procedure to enhance rigor in naturalistic research. Western Journal of Research Practice, 13(4):522-534.

HOUSE, H; MCALISTER, M \& NAIDOO, C 1990: Zimbabwe: Steps ahead. London: Catholic Institute for International Relations.

KIMCHI, J; POLIVKA, B \& STEVENSON, JS 1991: Triangulation: Operational definitions. Nursing Research, 40(6):364-366.

KIRK, J, \& MILLER, ML 1986: Reliability and validity in qualitative research. Qualitative research methods. Volume 1. Beverly Hills: Sage Publications.

KLOPPER, H 1995: Vertrouenswaardigheid strategieë in kwalitatiewe navorsing. RAUCUR, 1(1):25-28.

KREFTING, L 1991: Rigor in qualitative research: The assessment of trustworthiness. The American Journal of Occupational

Therapy, 45(3):214-222.

KROGH, KS \& LINDSAY, PH 1999: Including people with disabilities in research: Implications for the field of augmentative and alternative communication. Augmentative and Alternative Communication, 15(4):222-233.

KRUEGER, RA 1988: Focus groups: A practical guide for applied research. Newbury: Sage Publications.

KRUEGER, RA 1993: Quality control in focus group research. (In: Morgan, DL ed. 1993: Successful focus groups. Advancing the state of the art. Newbury: Sage Publications).

LEEDY, PD 2001: Practical research: Planning and design; $7^{\text {th }}$ edition. New York: Macmillan Publishing Company.

LERNER, H \& ROSS, L 1991: Community health nurses and high risk infants: The current role of Public Law 99-457. Infants and Young Children, 4(1):46-53.

LUNDGREN-LINQUIST, B \& NORDHOLM, L 1993: Communitybased rehabilitation: A survey of disabled village children in Botswana. Disability and Rehabilitation, 15(3):83-89.

MATAS, JA; MATHY-LAIKKO, P; BEUKELMAN, DR \& LEGRESLEY, K 1985: Identifying the non-speaking population: a demographic study. Augmentative and Alternative Communication, 1(1):17-31.

MCCONKEY, R 1996: Innovations in evaluating services for people with intellectual disabilities. Chorley: Lisieux Hall Publishers.
MERTENS, DM 1998: Research methods in education and psychology. Integrating diversity with quantitative and qualitative approaches. Thousand Oaks: Sage Publications.

MORSE, JM 1996: What is a method? Qualitative Health Research, 6(4):467-468.

MUSHOLT, M 1995: Nursing services. (In: Karan, O \& Greenspan, S eds, 1995: Community rehabilitation services for people with severe disabilities. Boston: Butterworth-Heinemann).

NATIONAL PROGRAMME OF ACTION (NPA) 1999: National programme of action for children in South Africa: 2000 and Beyond. Pretoria: The Presidency.

O'TOOLE, B 1988: A community-based rehabilitation programme for pre-school disabled children in Guyana. International Journal of Rehabilitation Research, 11(4):323-334.

PESHKIN, A 1993: The goodness of qualitative research. Educational Researcher, 22:23-29.

RAMEY, CT \& RAMEY, SL 1992: Effective Early Intervention. Mental Retardation, 30(2):337-345.

RIFKIN, SB 1986: Lessons from community participation in health programmes. Health Policy and Planning, 1(3):240-249.

SPENCER, JC 1993: The usefulness of qualitative methods in rehabilitation: Issues of meaning, of context and of change. Archives of physical medicine and rehabilitation, 47(1):119-126.

STANHOPE, MK 1995: Primary health care practice: Is nursing part of the solution or the problem? Family Community Health, 18(1):49-68.

THIPANYANA, M \& MAVUNDLA, T 1998a: The provision of primary health care in two rural districts of the Eastern Cape Province with particular reference to human resources and accessibility. Part 1. Curationis, 21(2):22-26.

THIPANYANA, M \& MAVUNDLA, T 1998b: The provision of primary health care in two rural districts of the Eastern Cape Province with particular reference to human resources and accessibility. Part 2. Curationis, 21(2):22-26.

THOMAS, SA 1999: Health care systems around the world. (In: Hitchcock, JE; Schubert, PE \& Thomas, SA eds. 1999: Community health nursing: Caring in action. Albany: Delmar Publishers).

THORBURN, MJ \& MARFO, K 1990: Practical approaches to childhood disability in developing countries: Insights from experience and research. Newfoundland: Memorial University of Newfoundland.

WEBB, C 1999: Analyzing qualitative data: Computerized and other approaches. Journal of Advanced Nursing, 29(2):323-330.

WERNER, D 1987: Disabled village children: A guide for community health workers, rehabilitation workers and families. Palo Alto: The Hesperian Foundation.

WILKEY, SF \& GARDNER, SS 1999: The varied roles of community health nursing. (In: Hitchcock, JE; Schubert, PE \& Thomas SA eds. 1999: Community health nursing: Caring in 
action. Albany: Delmar Publishers).

WILLIS, EM; BIGGINS, AL \& DONOVAN, JE 1999: Populationfocused practice. (In: Hitchcock, JE; Schubert, PE \& Thomas,

SA eds. 1999: Community health nursing: Caring in action.
Albany: Delmar Publishers).

WORLD HEALTH ORGANISATION (WHO) 2000: Global tuberculosis control. Genève: World Heath Organisation.

\section{APPENDIX A: Summary of themes delineated after two independent focus groups with nurses}

\begin{tabular}{|c|c|c|}
\hline Main area & Sub areas & Specific issues \\
\hline \multirow[t]{4}{*}{$\begin{array}{l}\text { Disempo- } \\
\text { werment }\end{array}$} & $\begin{array}{l}\text { Lack of } \\
\text { knowledge }\end{array}$ & $\begin{array}{l}\text { - Disability } \\
\text { - Normal development, in particular sexual development which results in } \\
\text { abuse and rape } \\
\text { - Medical issues and problems } \\
\text { - Poor compliance with appointments and medication as well as } \\
\text { immunisations that are not up-to-date } \\
\text { - "Shop around" resulting in intervention starting very late } \\
\text { - passive: "don't take action" } \\
\text { - no follow-ups are done } \\
\text { - attitudes of nurses not always conducive to the establishment of } \\
\text { - How to access a disability grant } \\
\text { - How to access services }\end{array}$ \\
\hline & $\begin{array}{l}\text { Poor } \\
\text { parenting } \\
\text { skills }\end{array}$ & $\begin{array}{l}\text { - Unaware of seriousness / not concerned } \\
\text { - Impact on siblings, e.g. siblings have behaviour problems such as } \\
\text { - } \text { juvenile delinquency } \\
\text { - Lack initiative } \\
\text { - Overprotect or abandon children } \\
\text { - Deprivation } \\
\text { - Young mothers do not care for their typically developing children } \\
\text { (come to school dirty, hungry, sick, etc.). This phenomenon is even } \\
\text { more prevalent in CSDs }\end{array}$ \\
\hline & Poverty & $\begin{array}{l}\text { - Transport } \\
\text { - struggle to use public transport to school and clinic } \\
\text { - } \quad \text { some public transport does not take wheelchairs } \\
\text { - } \quad \text { Clinic attended infrequently (cannot afford) } \\
\text { - } \quad \text { Lack of own homes and thus live with relatives }\end{array}$ \\
\hline & $\begin{array}{l}\text { Limited } \\
\text { resources }\end{array}$ & $\begin{array}{l}\text { - Schools } \\
\text { - limited and scattered: people unaware of them } \\
\text { - expensive } \\
\text { - long waiting lists } \\
\text { - Wheelchairs (acquiring and repairing) } \\
\text { - Untrained teachers } \\
\text { - } \quad \text { No control of quality of services }\end{array}$ \\
\hline
\end{tabular}




\begin{tabular}{|c|c|c|}
\hline & $\begin{array}{l}\text { Unemploy- } \\
\text { ment }\end{array}$ & $\begin{array}{l}\text { - } \quad \text { No support, have to care for CSDs - cannot work } \\
\text { Very young mothers are poorly qualified, thus earn low wages and } \\
\text { have difficulties to pay trained caregivers }\end{array}$ \\
\hline & Illiteracy & High incidence of illiteracy in community, especially among women \\
\hline & $\begin{array}{l}\text { Lack of } \\
\text { support }\end{array}$ & $\begin{array}{l}\text { ejection and blame from family } \\
\text { - } \quad \text { Good prognosis if supported by partner }\end{array}$ \\
\hline \multirow[t]{4}{*}{$\begin{array}{l}\text { External } \\
\text { influences }\end{array}$} & Religion & $\begin{array}{l}\text { elps with acceptance } \\
\text { - } \\
\text { - } \quad \text { Rome experience it as a "act of God" } \\
\text { - } \quad \text { Pray at home } \\
\text { - } \quad \text { Angry with God }\end{array}$ \\
\hline & $\begin{array}{l}\text { Culture and } \\
\text { tradition }\end{array}$ & $\begin{array}{l}\text { ely on traditional healers: go there first } \\
\text { - Believe witchcraft caused disability } \\
\text { - Older people believe contraceptives cause disability and blame nurses } \\
\text { - } \quad \text { customs do family planning }\end{array}$ \\
\hline & Family & $\begin{array}{l}\text { mpact on siblings: they do not want to be identified } \\
\text { - } \quad \text { Both primary caregivers work } \\
\text { - } \quad \text { Single mother families and many unmarried mothers } \\
\text { - } \quad \text { New partners do not accept } \\
\text { - } \quad \text { Big families, have many other children to attend to } \\
\text { - } \quad \text { Rejection by family and in-laws } \\
\text { - } \quad \text { Family disorganisation } \\
\text { - } \quad \text { Very young mothers or elderly mothers }\end{array}$ \\
\hline & Community & $\begin{array}{l}\text { neducated regarding disability } \\
\text { - } \quad \text { Stigmatises and/or rejects family of CSD } \\
\text { - } \quad \text { Ostracises \& blames family of CSD } \\
\text { - } \quad \text { Attacks integrity of profession - (impression: a nurse who has a } \\
\text { CSD cannot really know what is what) } \\
\text { - Needs community outreach (especially into schools and churches) }\end{array}$ \\
\hline $\begin{array}{l}\text { Emotional } \\
\text { problems }\end{array}$ & $\begin{array}{l}\text { Range of } \\
\text { negative } \\
\text { problems are } \\
\text { experienced }\end{array}$ & 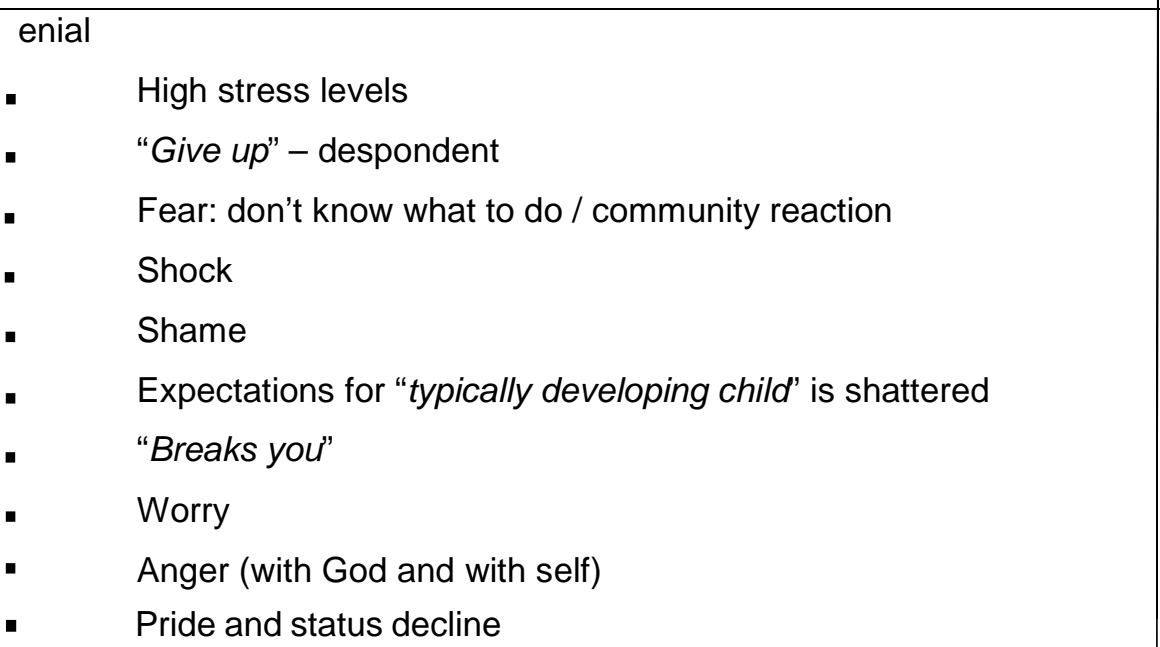 \\
\hline
\end{tabular}




\begin{tabular}{|c|c|c|}
\hline Impact & $\begin{array}{l}\text { Impact of } \\
\text { having a child } \\
\text { with a } \\
\text { disability is } \\
\text { seen at } \\
\text { different } \\
\text { levels }\end{array}$ & $\begin{array}{l}\text { ose status in the community } \\
\text { - Hide / dump the child } \\
\text { - Rejection by family / in-laws } \\
\text { - Bamily members blame each other } \\
\text { - Sexual abuse and sex for money (CSDs) }\end{array}$ \\
\hline \multicolumn{3}{|c|}{ Theme 2: How do nurses perceive their role and what they currently do? } \\
\hline \multirow[t]{6}{*}{$\begin{array}{l}\text { Services } \\
\text { provided }\end{array}$} & $\begin{array}{l}\text { Identifica- } \\
\text { tion and } \\
\text { detection }\end{array}$ & $\begin{array}{l}\text { btain case history and background information } \\
\text { hould screen, but unsure how to do this } \\
\text { hysical examination }\end{array}$ \\
\hline & $\begin{array}{l}\text { Providing } \\
\text { support }\end{array}$ & $\begin{array}{l}\text { rovide advice, although it is difficult to provide disability specific advice. } \\
\text { ostly general advice, e.g. regarding nutrition } \\
\text { rovide counselling (comfort) and family planning }\end{array}$ \\
\hline & $\begin{array}{l}\text { Health } \\
\text { promotion } \\
\text { and co- } \\
\text { ordination } \\
\text { of CBR } \\
\text { activities }\end{array}$ & $\begin{array}{l}\text { ealth promotion } \\
-\quad \text { Nutrition } \\
-\quad \text { Hygiene } \\
\text { BR-Activities } \\
-\quad \text { Accident prevention } \\
-\quad \text { Awareness campaigns } \\
-\quad \text { Leadership } \\
-\quad \text { Co-ordination }\end{array}$ \\
\hline & $\begin{array}{l}\text { Treatment } \\
\text { of minor } \\
\text { ailments }\end{array}$ & reatment of common colds, cuts, fever, gastro enteritis, etc. \\
\hline & Referral & $\begin{array}{l}\text { - Hospital (secondary / tertiary) } \\
\text { - Social worker } \\
\text { - Therapist } \\
\text { - School } \\
\text { - Medical specialist } \\
\text { - Religious support } \\
\text { - Genetic clinic } \\
\text { - Hospitals refer back to clinics despite the fact that clinics are often } \\
\text { - } \text { unable to offer any services } \\
\text { - No feedral line problematic } \\
\text { - Oftern primary caregivers do not attend referred service due to } \\
\text { transport problems }\end{array}$ \\
\hline & $\begin{array}{l}\text { Follow-up } \\
\text { to monitor }\end{array}$ & - Difficult, due to limited time and manpower \\
\hline
\end{tabular}




\begin{tabular}{|c|c|c|}
\hline \multicolumn{3}{|c|}{$\begin{array}{l}\text { Theme 3: Problems experienced by nurses (This information was spontaneously provided and } \\
\text { not probed for) }\end{array}$} \\
\hline \multirow{3}{*}{$\begin{array}{l}\text { Emotional } \\
\text { status }\end{array}$} & epressed & urses do not feel supported by the secondary and tertiary levels of care \\
\hline & ncapable & $\begin{array}{l}\text { eel that they are not helping primary caregivers of CSDs optimally as they } \\
\text { eed knowledge and skills }\end{array}$ \\
\hline & $\begin{array}{l}\text { egative } \\
\text { ttitude }\end{array}$ & egativity is caused limited staff and time constraints \\
\hline $\begin{array}{l}\text { Working } \\
\text { conditions }\end{array}$ & $\begin{array}{l}\text { imited } \\
\text { esources }\end{array}$ & $\begin{array}{l}\text { imited manpower; therefore have to rush patients through clinics } \\
\text { annot refer to school nurses as they too have limited resources and } \\
\text { ptions for placing CSDs } \\
\text { o follow-ups are done, despite the importance thereof } \\
\text { o co-ordination of staff }\end{array}$ \\
\hline \multicolumn{3}{|c|}{ Theme 4: Nurses' experiences } \\
\hline Exposure & $\begin{array}{l}\text { Exposure } \\
\text { to CSDs }\end{array}$ & $\begin{array}{l}\text { epends on setting (e.g. school nurses and nurses at the genetic clinic see } \\
\text { SDs more often) } \\
\text { - Some never see any CSDs } \\
\text { - Comment: Although exposure might be limited, the impact is high as } \\
\text { most nurses can recall details of clients even if they had not been } \\
\text { seen for more than a year. } \\
\text { - Comment: Nurses are keen to know more about disability } \\
\text { because they acknowledge the fact that although they do not } \\
\text { frequently see CSDs at the clinics; they know that CSDs are } \\
\text { out there in the community. }\end{array}$ \\
\hline Knowledge & $\begin{array}{l}\text { Disability } \\
\text { types }\end{array}$ & $\begin{array}{l}\text { ntellectual impairment } \\
\text { - } \quad \text { Cerebral palsy (CP) } \\
\text { - } \quad \text { Sensory deficits (deaf or blind) } \\
\text { - } \quad \text { Epilepsy } \\
\text { - } \text { Hydrocephalic } \\
\text { - } \quad \text { Micro-cephalic } \\
\text { - } \quad \text { Physical appearance, e.g. strange or small for age } \\
\text { - } \quad \text { Neglect, e.g. blind after running into a fence } \\
\text { - } \quad \text { Abuse and sexual abuse } \\
\text { - } \quad \text { At-risk factors, e.g. multiple pregnancies, low birth weight }\end{array}$ \\
\hline Skills & $\begin{array}{l}\text { Identifica- } \\
\text { tion }\end{array}$ & $\begin{array}{l}\text { evelopmental milestones (children younger than } 2 \text { years) } \\
\text { - } \quad \text { Through schools (e.g. slow learner, repeated Grade } 1 \text { three times) } \\
\text { - } \text { Neighbours inform nurse who then does home-visit } \\
\text { - } \quad \text { If missed at birth, detect at baby clinic } \\
\text { - } \text { Go to traditional healers before clinics / hospitals } \\
\text { - } \quad \text { Come to clinics when applying for a disability grant }\end{array}$ \\
\hline
\end{tabular}




\begin{tabular}{|c|c|c|}
\hline \multirow[t]{2}{*}{$\begin{array}{l}\text { Work } \\
\text { context }\end{array}$} & $\begin{array}{l}\text { Problems } \\
\text { identified }\end{array}$ & $\begin{array}{l}\text { O follow-ups } \\
\text { - Lack of knowledge } \\
\text { - Lack of resources - deprived province (Northwest) } \\
\text { - Depression } \\
\text { - Shock "nasty experience to deliver a baby with a disability" }\end{array}$ \\
\hline & $\begin{array}{l}\text { Possible } \\
\text { solutions }\end{array}$ & $\begin{array}{l}\text { - Training of nurses } \\
\text { - Co-ordination of services for CSDs (education and health sectors) } \\
\text { - Government to supply an infrastructure }\end{array}$ \\
\hline \multicolumn{3}{|c|}{ Theme 5 What do nurses need? } \\
\hline \multirow[t]{5}{*}{ Knowledge } & Disability & $\begin{array}{l}\text { - What to do about problems (not only detect them!) } \\
\text { - How to identify and do a case history } \\
\text { - Focus on person not on the disability }\end{array}$ \\
\hline & $\begin{array}{l}\text { Screening: } \\
\text { "What to } \\
\text { look for" }\end{array}$ & $\begin{array}{l}\text { - } \text { At-risk factors } \\
\text { - } \quad \text { Established risk factors }\end{array}$ \\
\hline & $\begin{array}{l}\text { Referral } \\
\text { skills }\end{array}$ & $\begin{array}{l}\text { - } \text { Early referral } \\
\text { - Know referral line / route } \\
\text { - } \text { Refer to church for support } \\
\text { - Refer to social worker for grant }\end{array}$ \\
\hline & $\begin{array}{l}\text { Parent } \\
\text { training } \\
\text { skills }\end{array}$ & $\begin{array}{l}\text { - Family planning for CSDs to reduce number of pregnancies } \\
\text { - Guidance for primary caregivers on parenting skills for CSDs } \\
\text { (currently overprotect, which leads to learnt helplessness or } \\
\text { abandonment) } \\
\text { How to treat primary caregivers } \\
\text { - Training of peers and siblings to understand disability }\end{array}$ \\
\hline & Teamwork & $\begin{array}{l}\text { Collaboration with other professionals, e.g. school health nurses, } \\
\text { priests, social workers, teachers, midwives }\end{array}$ \\
\hline \multirow[t]{4}{*}{ Skills } & $\begin{array}{l}\text { Rapport } \\
\text { and } \\
\text { empathy }\end{array}$ & $\begin{array}{l}\text { - } \text { Comfort primary caregivers } \\
\text { - How to deal with primary caregivers } \\
\text { - How to put primary caregivers at ease } \\
\text { - How to encourage acceptance }\end{array}$ \\
\hline & $\begin{array}{l}\text { Training of } \\
\text { primary } \\
\text { caregivers }\end{array}$ & $\begin{array}{l}\text { - } \text { Parenting } \\
\text { - } \text { Accident prevation } \\
\text { - Guidance and nutrition } \\
\text { - Hygiene } \\
\text { - Household safety (e.g. paraffin and medicine) }\end{array}$ \\
\hline & $\begin{array}{l}\text { Establish and } \\
\text { foster a } \\
\text { support group }\end{array}$ & $\begin{array}{l}\text { - Primary caregivers to "break the silence" } \\
\text { - Primary caregivers should support and provide suggestions } \\
\text { - Success stories are needed as role models }\end{array}$ \\
\hline & $\begin{array}{l}\text { Nature of } \\
\text { service } \\
\text { delivery }\end{array}$ & $\begin{array}{l}\text { - Detection / identification of CSDs } \\
\text { - What to do. Bring skills to the people before referring! } \\
\text { - } \quad \text { Foster feedback and follow-ups (at home and at school) } \\
\text { - Be to provide examples and advice }\end{array}$ \\
\hline
\end{tabular}




\begin{tabular}{|l|l|l|}
\hline Attitudes & Establish- & - Own acceptance of CSDs before teaching primary caregivers to accept \\
ment of & - Love CSDs: "Have a big heart" \\
own & - Interest \\
positive & - Not irritable \\
attitude & - Feel supported and "cared for" \\
towards & - Morale and spirit of nurses should be pepped up \\
CSDs & - Empathy (not sympathy) \\
& $\begin{array}{l}\text { - Address and change parental attitudes } \\
\text { - Focus on abilities and skills }\end{array}$ \\
& - Focus on a person, not on a disability \\
& $\begin{array}{l}\text { - Peers - children do not have prejudices, adults instil them } \\
\text { Establish- } \\
\text { ment of a } \\
\text { positive } \\
\text { community } \\
\text { attitude } \\
\text { towards } \\
\text { CSDs }\end{array}$ & - Community awareness campaign \\
& - Erama / demonstration about severe disability \\
\hline
\end{tabular}

